仕上げモルタルの付着性に留する研究

(その 4 冬期施 [時について)

正会員重倉祐光 ${ }^{*}$

同逸見義男 $※$ 同○知野熊推 ${ }^{\text {倉本秀信 }}$ ※

1. ま充が

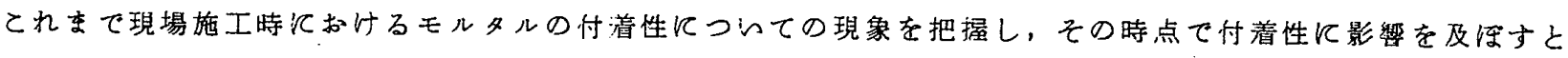
考察された要因をとり上げ室内奏験により検討をおこなった。本報告仕施工時期を特に問題の生じ易い冬期とし

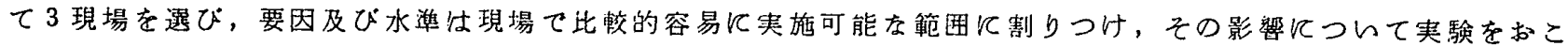
なったるのである。

2. 実 験 方 法

本肃験注ー 1 K示す5つの要因をL 27 型直交配列表に割りつけた。セメント及び混和材は研究所上り支給 するととによって3現場共統一したが，骨材のみは各現場のるのを使用した。

\title{
3. 実験結果及び考察
}

実験結果を表一2，3亿示した。

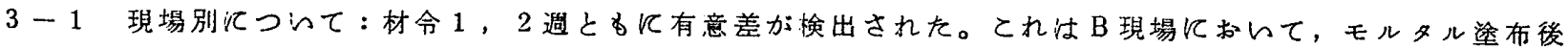

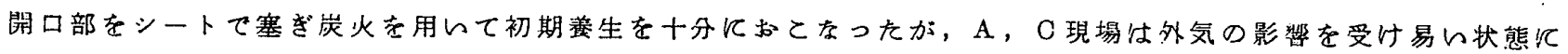
あったという条件差に上るものと思われる。2 造の平均強度で比较すると，A 現場 $5.80 \mathrm{Kg} / \mathrm{om}^{2}, \mathrm{C}$ 現場 $5.84 \mathrm{Kg} / \mathrm{om}$ に対し，B現場恃 $9.00 \mathrm{~kg} / \mathrm{om}$ あり約 1.5 倍の强度を示している。

3-2 セメント別につんて：材令 $1 ， 2$ 造とるに有意差が検出された。全般的に見て早強セメントの使用が

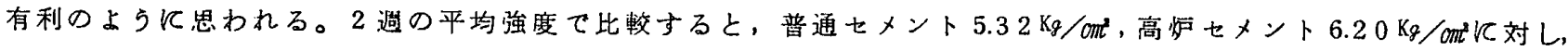
早強セメントは $9.10 \mathrm{Kg} / \mathrm{m}$ の值を示している。

$3-3$ 調合比別, 下地処理別，混和材別反つ 表ー2 割り付汁と実䮖結果 レて：んずれる有意差は愉出されなかった。この こと壮空内豪験の結果と一致しており冬期の現場 に於ても付前力を高める手段にはならない。

\section{表一 1 要因上水準}

\begin{tabular}{|c|c|c|c|c|c|c|}
\hline \multirow{2}{*}{ 要 } & \multirow{2}{*}{\multicolumn{2}{|c|}{ 因 }} & & \multicolumn{2}{|c|}{ 水 } & 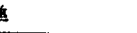 \\
\hline & & & & & 2 & 3 \\
\hline A. 現 & & & 场 & 見場 & B 现 均 & O 现 场 \\
\hline B. 調 & & & 比 & 2. 5 & $1: 3.0$ & $1: 3.5$ \\
\hline c. 混 & & & 材 & ーン & $\mathrm{M} \cdot \mathrm{C}$ 系 & ポノララン采 \\
\hline D. $t$ & $x$ & ע & r & & 早强 & 高奶 \\
\hline E. $F$ & 地 & 如 & 理 & $L$ & L \& & ワイヤ，水しめ \\
\hline
\end{tabular}

韭一3 分散分析表

\begin{tabular}{|c|c|c|c|c|c|c|c|c|}
\hline \multirow{2}{*}{\multicolumn{2}{|c|}{ 要 }} & \multirow{2}{*}{\multicolumn{2}{|c|}{ 因 }} & \multirow{2}{*}{ 自由路 } & \multicolumn{2}{|c|}{ 分 敖 品 } & \multicolumn{2}{|c|}{ 游写㳗 (b) } \\
\hline & & & & & 1 连 & 2 淔 & 1 邀 & 2 邂 \\
\hline A. 現 & & & 场 & 2 & $10.39: 39$ & $6.79 \because$ & 26.0 & 19.1 \\
\hline B. 調 & & & 比 & 2 & 428 & 387 & - & - \\
\hline G. 课 & & & 材 & 2 & 125 & 3.79 & - & - \\
\hline 1). $t$ & $x$ & ン & 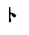 & 2 & 10.36 & $7.73: \vdots$ & 25.9 & 22.2 \\
\hline E. $F$ & 地 & 迈 & 쏘로 & 2 & 1.79 & 3.57 & & \\
\hline & & A & & 2 & 0.15 & 084 & & \\
\hline & $\mathrm{C}$ & B & & 2 & 1.79 & 0 & & \\
\hline & C & D & & 2 & 0.79 & 0.70 & & \\
\hline & & E & & 2 & 1.43 & 1.30 & & \\
\hline & & & & 8 & & & & \\
\hline
\end{tabular}

\begin{tabular}{|c|c|c|c|c|c|c|c|c|}
\hline \multirow{2}{*}{ A } & \multirow{2}{*}{$\begin{array}{c}\text { B } \\
\text { 调合比 } \\
\end{array}$} & \multirow{2}{*}{$\begin{array}{c}\mathrm{C} \\
\text { 湿和帆 }\end{array}$} & \multirow[t]{2}{*}{$\begin{array}{c}D \\
\text { セxント }\end{array}$} & \multirow{2}{*}{$\begin{array}{c}\text { E } \\
\text { 下地把 }\end{array}$} & \multicolumn{2}{|c|}{ 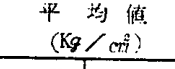 } & \multicolumn{2}{|c|}{ 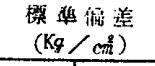 } \\
\hline & & & & & 1 渴 & 21 & 1 证 & 2 显 \\
\hline \multirow{6}{*}{ A } & $1: 2.5$ & \multirow{3}{*}{ プレーン } & & & 6.21 & 6.51 & 2.5 .7 & 1.92 \\
\hline & $1: 3.0$ & & & 水 $L$ 的 & 3.20 & 5.32 & 1.68 & 1.69 \\
\hline & $1: 3.5$ & & 㵧 & 王侎，水L的 & 4.11 & 5.06 & 2.62 & 2.01 \\
\hline & $1: 2.5$ & \multirow{3}{*}{ M. C 系 } & 賞 通 & & 2.51 & 3.59 & 0.64 & 1.14 \\
\hline & $1: 3.0$ & & & 水 L 加 & 7.20 & 8.69 & 2.54 & 3.22 \\
\hline & $1: 3.5$ & & & D什，水L:B & 4.96 & 6.67 & 1.97 & 2.15 \\
\hline & $1: 2.5$ & \multirow{3}{*}{ ボゲう } & 粪 䧈 & & 2.55 & 503 & 1.10 & 2.28 \\
\hline & $1: 3.0$ & & & 孙 L b & 6.31 & 5.07 & 1.84 & 2.01 \\
\hline & $1: 3.5$ & & 五 & D隹，冰しめ & $3 . \overline{2} 7$ & 6.26 & 0.87 & 2.98 \\
\hline \multirow{9}{*}{ B } & $1: 2.5$ & & 强 & ワイヤ、水しか & 12.56 & 17.20 & 3.22 & 5.77 \\
\hline & $1: 3.0$ & & 高 & & 8.54 & 7.96 & 1.86 & 2.12 \\
\hline & $1: 3.5$ & & 道 & 水 $L$ & 4.78 & 8.2 .1 & 2.05 & 1.57 \\
\hline & $1: 2.5$ & \multirow{3}{*}{ M. C 系 } & 强 & 7什，水し内 & 12.02 & 15.65 & 4.50 & 3.58 \\
\hline & $1: 3.0$ & & 西 & & 6.46 & 8.11 & 2.20 & 1.99 \\
\hline & $1: 3.5$ & & 鄫 通 & 水 $L$ 动 & 4.83 & 4.83 & 1.70 & 1.07 \\
\hline & $1: 2.3$ & \multirow{3}{*}{ ポンラン系 } & 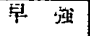 & 什。水L的 & 11.60 & 8.96 & 4.60 & 2.60 \\
\hline & $1: 3.0$ & & 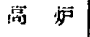 & & 6.43 & 5.93 & $1.7 \mathrm{I}$ & 3.01 \\
\hline & $1: 3.5$ & & 业 通 & is $L$ 专 & 5.31 & 4.16 & 2.02 & 1.60 \\
\hline \multirow{9}{*}{$\mathrm{C}$} & $1: 2.5$ & \multirow{3}{*}{ ブレー } & 酶 & * L i & 7.46 & 6.91 & 1.13 & 2.7 .4 \\
\hline & $1: 3.0$ & & 棠 油 & ワイ个，水しD & 5.17 & 5.76 & 1.35 & 1.83 \\
\hline & $1: 3.5$ & & 果琼 & $2 \quad L$ & 9.43 & 8.13 & 2.49 & 2.66 \\
\hline & $1: 2.5$ & \multirow{3}{*}{ M. C 系 } & ifj & 水 $L$ is & 6.03 & 5.98 & 2.21 & 2.43 \\
\hline & $1: 3.0$ & & 新 & $\nabla$ 什，水し以 & 3.51 & 4.22 & 1.19 & 1.48 \\
\hline & $1: 3.5$ & & 苹 海 & 太 $\quad$. & 7.64 & 8.96 & 2.50 & 2.29 \\
\hline & $1: 2.3$ & \multirow{3}{*}{ ポソラン系 } & 要 & 水 $L$ B & 6.18 & 2.91 & 2.09 & 1.44 \\
\hline & $1: 3.0$ & & & D什，水L的 & 5.83 & 5.55 & 2.04 & 0.77 \\
\hline & $1: 3.5$ & & 强 & & 2.59 & 3.82 & 1.36 & 0.72 \\
\hline
\end{tabular}

※ 藤田組技術研究所 